\title{
How I do it: surgical management of maxillary sinus hemangiomas via prelacrimal approach*
}

Luan Viet Tran 1,2, Lam Thanh Le², Peter John Wormald³

1Department of Otolaryngology Head and Neck Surgery, Pham Ngoc Thach University of Medicine, Ho Chi Minh city, Vietnam 2Department of Rhinology, Ear Nose Throat Hospital of Ho Chi Minh city, Ho Chi Minh city, Vietnam

3Department of Surgery - Otolaryngology Head and Neck Surgery, Adelaide University, Adelaide, Australia
Rhinology 58: 4, 410 - 412, 2020

https://doi.org/10.4193/Rhin20.178

*Received for publication:

April 21, 2020

Accepted: May 11, 2020

\section{To the Editor:}

Hemangiomas are tumours originating from the vascular endothelium and can be found throughout the body. These are relatively common in the head and neck regions but very rarely seen in sinonasal region. In the nose and sinuses tumours typically are seen on the septum or lateral nasal wall ${ }^{(1-4)}$. These tumours can be quite vascular and bleed during attempted resection. Incomplete resection does result in residual disease or recurrence so the best approach to achieve complete resection is important. A case review of 6 patients presenting with maxillary sinus hemangiomas is presented with a focus on the presentation, radiological diagnostic criteria and surgical technique required to achieve complete resection. This study was approved by the ethics committee of Pham Ngoc Thach University of Medicine. During the period November 2018 to August 2019, 6 patients presented to the Ear Nose Throat Hospital of Ho Chi Minh city - Vietnam. Two patients had undergone prior surgery at other institutions prior to presenting to our institution. All patients underwent endoscopic sinus surgery with a prelacrimal approach (PLA) under general anesthesia. Any hemangioma protruding through the maxillary ostium into the nasal cavity was debulked. A large middle meatal antrostomy was performed. A PLA was performed by placing a curved incision on the lateral nasal wall, anterior to the head of inferior turbinate. The mucoperiosteal flap was raised, the bony inferior turbinate head was exposed and used as a landmark to identify placement of the osteotomies. The bone of the inferior turbinate head was removed with a chisel or drill exposing the nasolacrimal duct (NLD). The bone around the NLD was removed giving a large exposure into the maxillary sinus anterior to the NLD. The medial bony wall of maxillary sinus was excised from the maxillary sinus roof to the floor to create maximal access to maxillary sinus. This allowed complete excision of the tumour with a margin of normal mucosa around the tumour attachment. The flap was then repositioned and sutured (Figure 1).

The diagnosis of hemangioma was confirmed with post-operative pathologic results in all cases: 4 cases with cavernous he- mangioma, and 2 cases with lobular capillary hemangioma. The most common symptoms were unilateral epistaxis (100\%) and nasal obstruction (66.7\%); facial pressure was noted in $50 \%$ of cases. Pre-operative nasal endoscopy showed the tumour extended largely into the nasal cavity through maxillary ostium in 4 patients in which the tumour appeared to have a purple colour with bleeding from the tumour in two patients; and a polyp-like appearance in two others. One patient had normal nasal polyp appeared to cover the tumour protruding through the maxil-

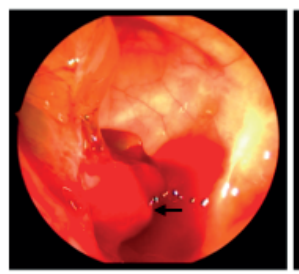

A

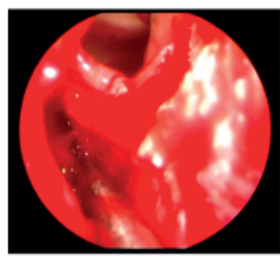

D

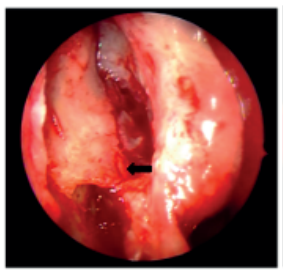

B

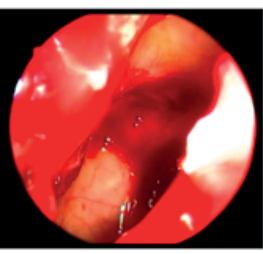

E

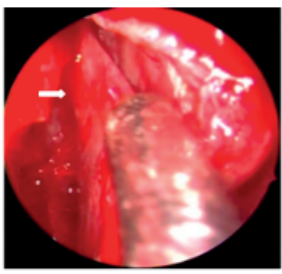

C

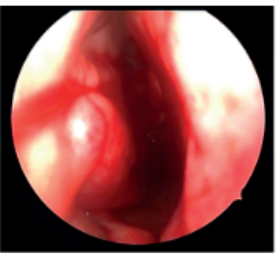

F
Figure 1. Maxillary sinus hemangioma resection via PLA on the righthand side in a recurrent case. $(\mathrm{A})$ nasal polyp was debrided through middle meatal antrostomy, hemangioma was detected originating from anterior wall of maxillary sinus. (B) mucoperiosteal flap was raised, the bony inferior turbinate head was exposed. (C) NLD was exposed and dislocated medially with the flap. (D) medial bony wall was excised, the tumour's attachment was dissected out of anterior wall of maxillary sinus. (E) anterior wall has no remnant hemangioma, observed with 45-degree scope via PLA. (F) the flap was repositioned and sutured. (black thin arrow: hemangioma originating from anterior wall; black thick arrow: bony inferior turbinate head; white thick arrow: NLD). 

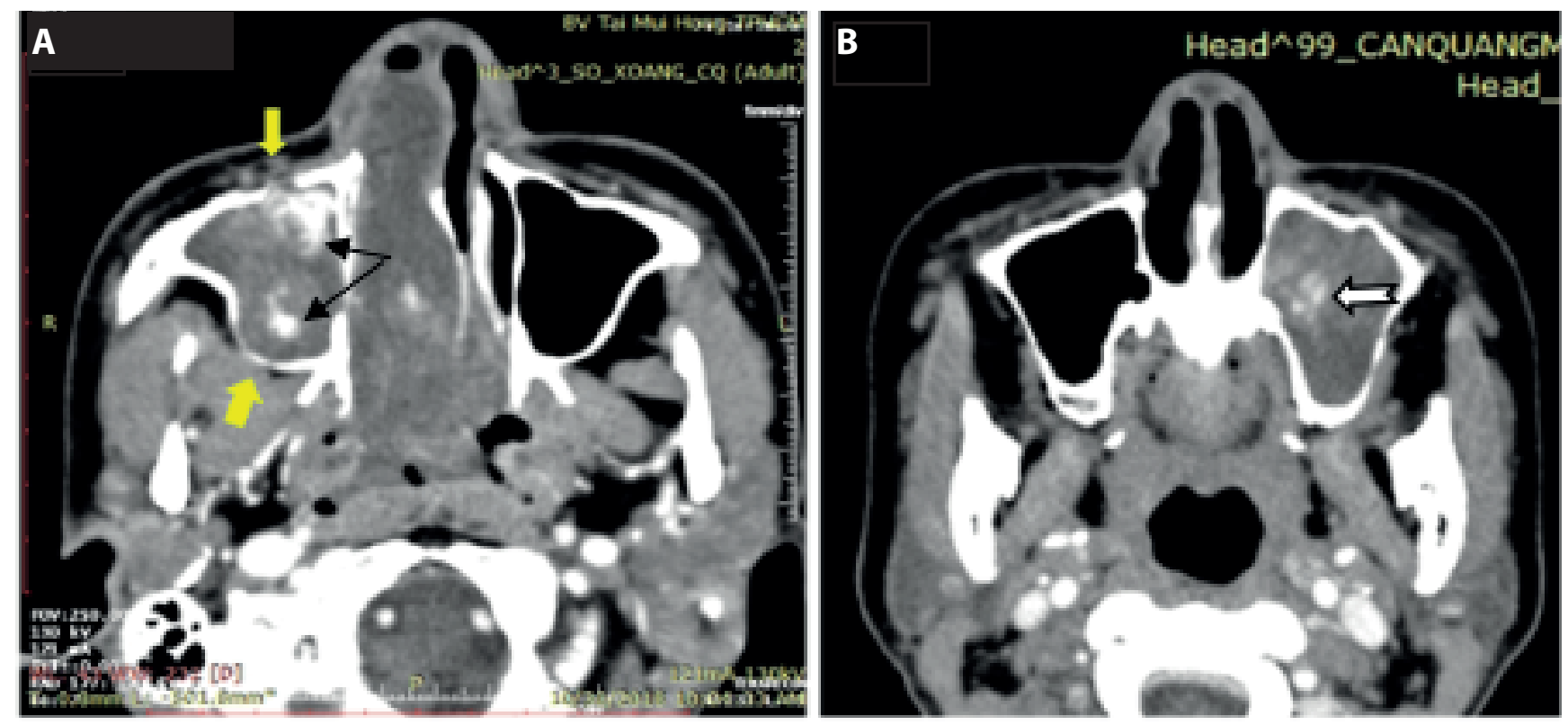

Figure 2. CT scan with contrast showed maxillary sinus hemangiomas with multifocal nodular (black arrows) (A) and centripetal (white arrow) (B) strong enhancement. Erosion of anterior and posterior wall of maxillary sinus was also noted (yellow arrows).

lary ostium. One patient had no visible tumour in the middle meatus. The preoperative CT scan showed an inhomogeneous tissue mass in the maxillary sinus in all cases. In 5 cases with contrast, multifocal nodular or centripetal strong enhancement was seen, suggesting a hemangioma (Figure 2). Bony remodeling of maxillary sinus was noted in 5 cases. Medial wall erosion around maxillary sinus ostium was noted in all cases, including the 2 revision cases. Bony erosion was also detected at other maxillary sinus walls in 4 cases (Table 1). All cases had some tumour extension into the nasal cavity including 2 cases within middle meatus (one not visible on endoscopy but seen on CT scan) and 4 cases out of middle meatus. Tumour excision was performed as previously described with an average blood loss of $265 \mathrm{ml}$. No intra-operative complications occurred with no post-operative epiphora or numbness. No recurrence was noted during the follow-up period which ranged from 3 to 12 months.

This is the largest case cohort of sinonasal maxillary hemagiomas in the literature and gives insights into the presentation, CT scan appearance and surgical treatment. All patients presented with unilateral epistaxis similar to that seen by Puxeddu et al. ${ }^{(5)}$. Nasal obstruction was also frequent as hemangioma extended into nasal cavity. Endoscopically the nasal component was purple but could be obscured by standard polyps. The radiological features seen on CT scan were typically a soft tissue inhomogenous mass, with multifocal nodular or centripetal strong enhancement. Bony erosion is often smooth suggesting an expansile mass rather than invasion. This is similar to features described by Kim et al. ${ }^{(6)}$. There was no difference in CT features between cavernous and capillary hemangioma in our study. The PLA was selected for our case cohort as it was unclear from the pre-operative radiologically where the tumour would be attached and this approach gives the widest possible access to the entire maxillary sinus specifically to the difficult to reach areas of the anterior and lateral wall of the sinus. This approach was first introduced by Zhou in 2007, mainly for resection of inverted papilloma in maxillary sinus ${ }^{(7)}$. While intraoperative bleeding was moderate in our cases (average $256 \mathrm{ml}$ ), some suggestions that pre-operative embolization is needed appear to be unfounded based on our case series ${ }^{(4,5)}$. We could not identify any main feeding artery in any of our patients. The sinus wall lining where the tumour was attached was smooth and consequently no bone drilling of the attachment was performed in order to prevent recurrence. Post-operative numbness due to injury of alveolar nerve endings could be avoided if the surgery is limited to the medial side of the piriform aperture.

Simmen et al classified the distance between the anterior wall of the maxillary sinus and the NLD into 3 types: type I ( $<3 \mathrm{~mm})$, type II (3-7mm) and type III ( $>7 \mathrm{~mm}$ ) and stated that a PLA to the maxillary sinus was often difficult without a temporary dislocation or even resection of the NLD in patients with type I ${ }^{(8)}$. Five cases in our study had type II and one case had type I distance. With regard to our patient with type I, we used diamond burr to expose the NLD before removing the bone from around the NLD allowing the NLD to be safely medially dislocated with the raised mucosal flap.

In conclusion, maxillary sinus hemangioma is a rare benign tumor presenting with unilateral epistaxis and nasal obstruction, with quite specific features on CT scan. A PLA gives good access and allows safe and effective removal of the maxillary sinus hemangioma. 
Table 1. Clinical manifestations, pathology results and CT features of our patients.

\begin{tabular}{|c|c|c|c|c|c|c|c|c|c|}
\hline N\# & Age & Sex & $\begin{array}{l}\text { Duration } \\
\text { (month) }\end{array}$ & Pathology & Symptoms & $\begin{array}{l}\text { Origin in } \\
\text { Maxillary } \\
\text { sinus }\end{array}$ & Extension & $\begin{array}{l}\text { CT with } \\
\text { contrast }\end{array}$ & $\begin{array}{l}\text { Bone } \\
\text { erosion }\end{array}$ \\
\hline 1 & 21 & $\mathrm{~F}$ & 84 & $\begin{array}{l}\text { cavernous } \\
\text { hemangioma }\end{array}$ & $\begin{array}{l}\text { epistaxis \& } \\
\text { nasal } \\
\text { obstruction }\end{array}$ & $\begin{array}{l}\text { anterior wall } \\
\text { and floor }\end{array}$ & $\begin{array}{l}\text { filled the nasal } \\
\text { cavity }\end{array}$ & $\begin{array}{l}\text { multifocal } \\
\text { nodular strong } \\
\text { enhancement }\end{array}$ & $\begin{array}{l}\text { anterior and } \\
\text { posterior } \\
\text { wall }\end{array}$ \\
\hline 2 & 39 & $\mathrm{~F}$ & 6 & $\begin{array}{l}\text { cavernous } \\
\text { hemangioma }\end{array}$ & epistaxis & $\begin{array}{l}\text { anterior wall } \\
\text { and floor }\end{array}$ & $\begin{array}{l}\text { within middle } \\
\text { meatus }\end{array}$ & $\begin{array}{l}\text { centripetal } \\
\text { strong enhan- } \\
\text { cement }\end{array}$ & $\begin{array}{l}\text { posterior } \\
\text { wall }\end{array}$ \\
\hline 3 & 26 & $\mathrm{~F}$ & 3 & $\begin{array}{l}\text { cavernous } \\
\text { hemangioma }\end{array}$ & epistaxis & $\begin{array}{l}\text { anterior wall } \\
\text { and floor }\end{array}$ & $\begin{array}{l}\text { within middle } \\
\text { meatus }\end{array}$ & non-contrast & none \\
\hline 4 & 38 & M & 0.25 & $\begin{array}{l}\text { cavernous } \\
\text { hemangioma }\end{array}$ & $\begin{array}{l}\text { epistaxis \& } \\
\text { nasal } \\
\text { obstruction }\end{array}$ & $\begin{array}{l}\text { anterior and } \\
\text { lateral wall }\end{array}$ & $\begin{array}{l}\text { extended into the } \\
\text { nasal cavity below } \\
\text { the edge of the } \\
\text { middle turbinate }\end{array}$ & $\begin{array}{l}\text { multifocal } \\
\text { nodular strong } \\
\text { enhancement }\end{array}$ & none \\
\hline 5 & 69 & $\mathrm{~F}$ & 0.5 & $\begin{array}{l}\text { capillary } \\
\text { hemangioma + } \\
\text { fungus }\end{array}$ & $\begin{array}{l}\text { epistaxis \& } \\
\text { nasal } \\
\text { obstruction }\end{array}$ & $\begin{array}{l}\text { anterior \& } \\
\text { lateral wall, } \\
\text { and floor }\end{array}$ & $\begin{array}{l}\text { extended into the } \\
\text { nasal cavity below } \\
\text { the edge of the } \\
\text { middle turbinate }\end{array}$ & $\begin{array}{l}\text { centripetal } \\
\text { strong } \\
\text { enhancement }\end{array}$ & $\begin{array}{l}\text { posterior } \\
\text { and lateral } \\
\text { wall }\end{array}$ \\
\hline 6 & 33 & $M$ & 12 & $\begin{array}{l}\text { capillary heman- } \\
\text { gioma }\end{array}$ & $\begin{array}{l}\text { epistaxis \& } \\
\text { nasal } \\
\text { obstruction }\end{array}$ & anterior wall & $\begin{array}{l}\text { filled the nasal } \\
\text { cavity }\end{array}$ & $\begin{array}{l}\text { centripetal } \\
\text { moderate } \\
\text { enhancement }\end{array}$ & anterior wall \\
\hline
\end{tabular}

\section{Authorship contribution}

LVT and LTL performed all the operations, collected and analysed the data. LVT prepared the manuscript. PJW revised the manuscript. All authors approved the final version of the manuscript. LVT submitted the manuscript.

\section{Conflict of interest}

The authors state that they have no conflict of interest.

\section{Acknowledgement}

the authors gratefully thank Dr Nguyen Huu Bao for reviewing CT scans of the patients".

\section{References}

1. Jammal H, Barakat F, Hadi U. Maxillary sinus cavernous hemangioma: a rare entity. Acta Otolaryngol 2004; 124: 331-3.

2. Kim JS, Kwon SH. Sinonasal Hemangioma: Diagnosis, Treatment, and Follow-Up of 37 Patients at a Single Center. J Oral Maxillofac Surg 2017; 75: 1775-83.

3. Vargas MC, Castillo M. Sinonasal cavernous haemangioma: a case report. Dentomaxillofac Radiol 2012; 41: 340-1.

4. Schlosser R, Woodworth BA, Gillespie MB, Day TA. Endoscopic resection of sinonasal hemangiomas and hemangiopericytomas. ORL J Otorhinolaryngol Relat Spec 2006; 68: 69-72

5. Puxeddu R, Berlucchi M, Ledda GP, Parodo G, Farina D, Nicolai P. Lobular capillary hemangioma of the nasal cavity: A retro- spective study on 40 patients. Am J Rhinol 2006; 20: 480-4

6. Kim JH, Park SW, Kim SC, et al. Computed tomography and magnetic resonance imaging findings of nasal cavity hemangiomas according to histological type. Korean J Radiol 2015; 16: 566-74.

7. Zhou B, Huang Q, Sun J, et al. Resection of Inverted Papilloma of the Maxillary Sinus via a Prelacrimal Recess Approach: A Multicenter Retrospective Analysis of Surgical Efficacy. Am J Rhinol Allergy 2018; 32: 518-25.

8. Simmen D, Veerasigamani $N$, Briner $H R$ Jones N, Schuknecht B. Anterior maxillary wall and lacrimal duct relationship - CT analysis for prelacrimal access to the maxillary sinus. Rhinology 2017; 55: 170-4.

\section{Luan Viet Tran}

Department of Otolaryngology

Head and Neck Surgery

Pham Ngoc Thach University of

Medicine

02 Duong Quang Trung, District 10

Ho Chi Minh city

Vietnam

Tel: +84-28-38652435

Fax: +84-28-38650025

E-mail: luantranviet@gmail.com 